\title{
Leczenie wenetoklaksem młodego pacjenta z przewlekłą białaczką limfocytową z delecją 17p i nawrotem choroby po pierwszej linii leczenia - opis przypadku i przegląd literatury
}

\author{
Young CLL patient with 17p deletion and relapse \\ after immunochemotherapy treated with venetoclax \\ - case report and literature review
}

\author{
Anna Dąbrowska-Iwanicka (D, Katarzyna Błachnio, \\ Renata Woroniecka (D), Grzegorz Rymkiewicz (D), Jan Walewski (D) \\ Klinika Nowotworów Układu Chłonnego Narodowego Instytutu Onkologii \\ im. Marii Skłodowskiej-Curie — Państwowego Instytutu Badawczego w Warszawie
}

\begin{abstract}
Streszczenie
Przewlekta biataczka limfocytowa (CLL) jest najczésciej wystęująca choroba limfoproliferacyjna wywodzaca sie $z$ limfocytów B $i$ biataczkq $w$ populacji osób dorostych w krajach zachodnich. Populacja pacjentów obejmuje gtównie starszych chorych, $z$ medianq wieku zachorowań wynoszaca 72 lata. Czas przeżycia waha sie od 2 do okoto 15 lat i zależy od czynników kliniczno-patologicznych, takich jak: stopień zaawansowania, wiek, obecność aberracji genetycznych, z których najbardziej niekorzystny wplyw maja aberracje genu TP53. Rozpoczecie leczenia jest uwarunkowane obecnościa choroby aktywnej i objawowej zdefiniowanej przez grupe robocza CLL oraz wysokim stopniem zaawansowania klinicznego ocenianym w skali Raia lub Bineta. Terapie CLL w ostatnich latach zrewolucjonizowano, wprowadzajac substancje bedace inhibitorami matych czasteczek i dziatajacych na szlaki sygnatowe w komórce. Leki te wykazaty się znacznie większa skutecznościa niz tradycyjna immunochemioterapia - zarówno u pacjentów nieleczonych, jak i postaciach nawrotowych - co przejawia sie przede wszystkim poprawa parametrów przeżcia i doprowadzito do zmiany zaleceń terapeutycznych. Dzięki nowym lekom poprawito sie rokowanie pacjentów $z$ postaciami CLL najwyzszego ryzyka $-z$ aberracjami TP53 $i$ ztożonym kariotypem, ale nadal pozostaje ono gorsze niz w pozostatych grupach chorych. Otwarte pozostaja kwestie optymalnego sekwencjonowania terapii i miejsca allogenicznego przeszczepienia szpiku u tych chorych.
\end{abstract}

Słowa kluczowe: przewlekła białaczka limfocytowa, CLL, aberracje TP53, delecja 17p, inhibitory kinazy tyrozynowej Brutona, inhibitory BCL2, allogeniczne przeszczepienie szpiku kostnego

Hematologia 2020; 11, 4: 240-252

\section{Abstract}

Chronic lymphocytic leukaemia (CLL) is the commonest B-cell malignancy and leukaemia in western countries. It mainly affects the elderly population with a median age of 72. Overall survival varies from 2 to 15 years and depends on clinical and pathological risk factors like age, clinical

Adres do korespondencji: Anna Dąbrowska-Iwanicka, Klinika Nowotworów Układu Chłonnego, Narodowy Instytut Onkologii im. Marii Skłodowskiej-Curie — Państwowy Instytut Badawczy, ul. Roentgena 5, 02-781 Warszawa, tel. +48 2254626 18, e-mail: anna.dabrowska-iwanicka@pib-nio.pl 
stage and the presence of genetic mutations with TP53 aberrations conferring the worst prognosis. Indications for therapy include active and symptomatic disease and advanced clinical stage assessed in the Rai or Binet staging system. CLL therapy has been revolutionized in the last years due to the introduction of novel agents - small molecule inhibitors interfering with signalling pathways. These agents proved to be of greater efficacy than immunochemotherapy in both untreated and relapsed patients and led to the significant improvement in survival of CLL patients. These novel agents have been incorporated into new recommendations for CLL treatment. They have also improved the survival of high-risk CLL patients with TP53 aberrations and complex karyotype although their prognosis is still inferior as compared to other patients' subgroups. Questions concerning optimal sequencing novel agents and the timing of allogeneic bone marrow transplantation remain still open for high-risk group CLL patients.

\section{Key words: chronic lymphocytic leukaemia, CLL, TP53 aberration, deletion 17p, Bruton tyrosine kinase inhibitor, BCL2 inhibitor, allogeneic bone marrow transplantation}

Hematologia 2020; 11, 4: 240-252

\section{Wprowadzenie}

Przewlekła białaczka limfocytowa (CLL, chronic lymphocytic leukemia) jest najczęściej występującą chorobą limfoproliferacyjną wywodzącą się z limfocytów B i białaczką w populacji osób dorosłych w krajach zachodnich, o częstości występowania 4,2 przypadku/100 000 osób. Mediana wieku zachorowań wynosi 72 lata i obserwuje się przewagę mężczyzn w stosunku do kobiet $(1,7: 1)$. Rozpoznanie CLL wymaga stwierdzenia obecności co najmniej $5 \mathrm{G} / 1\left(5000 / \mathrm{mm}^{3}\right)$ klonalnych limfocytów B we krwi obwodowej przez minimum 3 miesiące. Typowy fenotyp powinien zostać potwierdzony metodą cytometrii przepływowej i obejmuje panel CD5+, CD20+, CD19+, CD23+, CD43+, CD200+ oraz obecność łańcuchów lekkich immunoglobulin kappa lub lambda na powierzchni komórek. W przypadku występowania limfadenopatii bez cytopenii i z liczbą monoklonalnych limfocytów B nieprzekraczającą $5 \mathrm{G} / 1$ dokonuje się rozpoznania chłoniaka $z$ małych limfocytów (SLL, small lymphocytic lymphoma), po potwierdzeniu nacieku chłoniaka w badaniu histopatologicznym wycinków $z$ węzła chłonnego lub innych zajętych przez chorobę tkanek. W klasyfikacji Światowej Organizacji Zdrowia (WHO, World Health Organization) z 2016 roku CLL i SLL uznano za jedną jednostkę chorobową. Jeżeli stwierdza się limfocytozę z liczbą monoklonalnych limfocytów B nieprzekraczającą $5 \mathrm{G} / \mathrm{l}$ bez limfadenopatii, organomegalii i cytopenii, to wówczas jest rozpoznawana monoklonalna limfocytoza $z$ komórek B (MBL, monoclonal B-lymphocytosis). Ocenia się, że rocznie u 1-2\% pacjentów z MBL może dojść do progresji w CLL [1, 2].
Do oceny stopnia zaawansowania służą dwa systemy, Raia i Bineta, zgodnie $z$ którymi wśród pacjentów tworzy się grupy różniące się także rokowaniem. Podstawami obu systemów są ocena morfologii krwi obwodowej i limfadenopatia dostępna w badaniu palpacyjnym. W zmodyfikowanym systemie według Raia do grupy niskiego ryzyka zalicza się pacjentów tylko $z$ limfocytozą we krwi obwodowej i/lub szpiku; średniego ryzyka - ze współistniejącą limfadenopatią i/lub hepato- czy splenomegalią, a wysokiego ryzyka $-z$ niedokrwistością i stężeniem hemoglobiny $(\mathrm{Hb})$ poniżej $11 \mathrm{~g} / \mathrm{dl}$ i/lub małopłytkowością mniejszą niż $100 \mathrm{G} / \mathrm{l}$. $Z$ kolei w ocenie stopnia zaawansowania według Bineta pod uwagę bierze się liczbę zajętych okolic węzłowych i/lub wątroby oraz śledziony, przy czym węzły chłonne regionu głowy i szyi wraz z pierścieniem Waldeyera są zaliczane do jednej okolicy, drugą stanowią doły pachowe, a trzecią pachwiny i węzły chłonne udowe. Pacjenci bez niedokrwistości i małopłytkowości, $z$ limfadenopatią w jednej lub dwóch okolicach są zaliczani do grupy A; z zajęciem trzech i większej liczby okolic węzłowych/narządów i również bez cytopenii - do grupy $\mathrm{B}$, a chorzy z niedokrwistością i/lub małopłytkowością — do grupy C $[1,2]$.

W CLL można wyodrębnić aberracje chromosomalne i molekularne o uznanym znaczeniu rokowniczym. Do najczęściej występujących (50-60\%) należą delecja ramienia długiego chromosomu 13 (del13q14) o korzystnym wpływie na przeżycie, a następnie trisomia chromosomu 12 — oznaczająca ryzyko pośrednie (15-25\%) u chorych. Aberracjami o niekorzystnym znaczeniu rokowniczym są delecja 11q23 obejmująca gen $A T M$ (10-25\% pacjentów) i delecja $17 \mathrm{p} 13$ obejmująca 
TP53 (wyjściowo 5-10\% chorych) oraz mutacja TP53 (4-37\%). Ponadto udowodniono negatywny wpływ rokowniczy występowania niezmutowanego statusu genów dla łańcuchów ciężkich immunoglobulin (IGHV, immunoglobulin heavy chain variable), kompleksowego kariotypu ( $\geq 3$ czy, wg ostatnich publikacji, $\geq 5$ zmian), obecności określonych markerów immunofenotypowych, takich jak ZAP70+, CD38+, CD49d+, czy zwiększonego stężenia $\beta_{2}$-mikroglobuliny. Bada się również znaczenie prognostyczne mutacji w innych genach, takich jak NOTCH1, SF3B1, MYD88 i BIRC3, za pomoca sekwencjonowania nowej generacji (NGS, next-generation sequencing), ale ich ocena nie wchodzi jeszcze w skład standardowego panelu diagnostycznego [1,2]. W celu zintegrowania klinicznych i biologicznych, w tym molekularnych, czynników rokowniczych opracowano międzynarodowy wskaźnik prognostyczny dla CLL (CLL-IPI, CLL International Prognostic Index), w skład którego wchodzą: stężenie $\beta_{2}$-mikroglobuliny, obecność delecji $17 \mathrm{p}$ i/lub mutacji TP53, wiek, stopień zaawansowania klinicznego, status mutacji genu dla IGHV. Ocena tych pięciu czynników pozwala podzielić pacjentów na pięć grup rokowniczych różniących się rokowaniem - od przeżycia 5-letniego wynoszącego 93,2\% w grupie niskiego ryzyka do wynoszącego $23,3 \%$ w grupie ryzyka bardzo wysokiego [3].

Zgodnie $z$ wytycznymi Międzynarodowej Grupy Roboczej dla CLL (iwCLL, International Working Group-CLL) leczenie jest rozpoczynane $\mathrm{w}$ momencie wystąpienia co najmniej jednego z określonych wskazań, do których zalicza się: niedokrwistość ze stężeniem $\mathrm{Hb}$ poniżej $10 \mathrm{~g} / \mathrm{dl}$ i/lub małopłytkowość poniżej $100 \mathrm{G} / 1$, masywną postępującą splenomegalię, objawowe i/lub znaczne powiększenie węzłów chłonnych ponad $10 \mathrm{~cm}$, narastającą limfocytozę - wzrost o 50\% w ciągu 2 miesięcy lub podwojenie liczby limfocytów w czasie krótszym niż 6 miesięcy; niedokrwistość lub małopłytkowość pochodzenia autoimmunologicznego, objawowe zajęcie narządów pozawęzłowych, objawy układowe (w tym dodatkowo znaczne zmęczenie). Sama, nawet wysoka, absolutna wartość limfocytozy nie jest wskazaniem do rozpoczęcia leczenia [2].

Wybór terapii zależy od dwóch najważniejszych parametrów - stanu pacjenta, wieku i chorób współistniejących (do oceny których mogą byś stosowane specjalistyczne skale jak CIRS $(\mathrm{Cu}$ mulative Illness Rating Scale) oraz czynników biologicznych, $z$ których najważniejszym jest obecność delecji/mutacji TP53 oraz status mutacji IGHV. Wprowadzenie nowych leków - małocząsteczko- wych inhibitorów - zmieniło standardy leczenia w CLL, które wcześniej głównie opierały się na cytostatykach — analogach puryn i lekach alkilujących $z$ przeciwciałami monoklonalnymi anty-CD20. Do nowych leków należą inhibitory kinaz interferujące ze szlakami sygnałowymi $z$ receptora $B$ (BCR, B-cell receptor), z których najważniejszymi są inhibitory kinazy tyrozynowej Brutona (BTK, Bruton tyrosine kinases) (ibrutynib, akalabrutynib), inhibitory kinazy fosfatydylo-3-inozytolu (PI3K, phosphatidylinositol 3-kinase) (idelalisib) oraz lek hamujący działanie antyapoptotycznego białka BCL2 - wenetoklaks. Aktywność tych leków, zarówno w postaciach nawrotowych i opornych, jak i w pierwszej linii leczenia, potwierdzono w randomizowanych badaniach klinicznych, których omówienie wykracza poza ramy niniejszego artykułu, a jest wyrażona istotnym wydłużeniem odsetków odpowiedzi, czasu wolnego od progresji (PFS, progression-free survival) (w niektórych przypadkach również przeżycia całkowitego [OS, overall survi$v a l])$, efektywnością w eradykacji minimalnej choroby resztkowej (MRD, minimal residual disease) i leczeniu pacjentów $z$ niekorzystnymi aberracjami genetycznymi, w tym ze zmianami w genie TP53. Aktualne zalecenia mogą się nieco różnić zależnie od dostępności preparatów, interpretacji wyników badań klinicznych i korzyści ze stosowania nowych leków w poszczególnych grupach pacjentów. Immunochemioterapia według schematu R-FC (rytuksymab, fludarabina, cyklofosfamid), która przez lata pozostawała podstawą leczenia, obecnie ma najsilniejszą rekomendację dla pacjentów poniżej 65. roku życia ze zmutowanym IGHV, ponieważ u części tych chorych może doprowadzić do eradykacji MRD. U nieleczonych młodszych pacjentów $z$ niezmutowanym IGHV zaleca się ibrutynib, wenetoklaks $z$ obinutuzumabem albo akalabrutynib $z$ obinutuzumabem lub bez obinutuzumabu. U chorych powyżej 65. roku życia, z obciążeniami, w pierwszej linii zaleca się również przeważnie schematy niezawierające leków cytostatycznych, takie jak ibrutynib, wenetoklaks $z$ obinutuzumabem, akalabrutynib $z$ obinutuzumabem, lub immunochemioterapię takimi lekami, jak chlorambucyl $z$ obinutuzumabem lub rytuksymab $z$ bendamustyną (u pacjentów ze zmutowanym IGHV, bez istotnych wielu chorób wspólistniejących). Pacjenci z delecja/mutacją TP53 powinni w pierwszej linii leczenia otrzymać nowe leki - inhibitory BTK albo anty-BCL2 [1, 2, 4, 5] (ryc. 1).

Odpowiedź na leczenie, ze standardowym podziałem na odpowiedź całkowitą (CR, complete response), odpowiedź częściową ( $\mathrm{PR}$, partial res- 


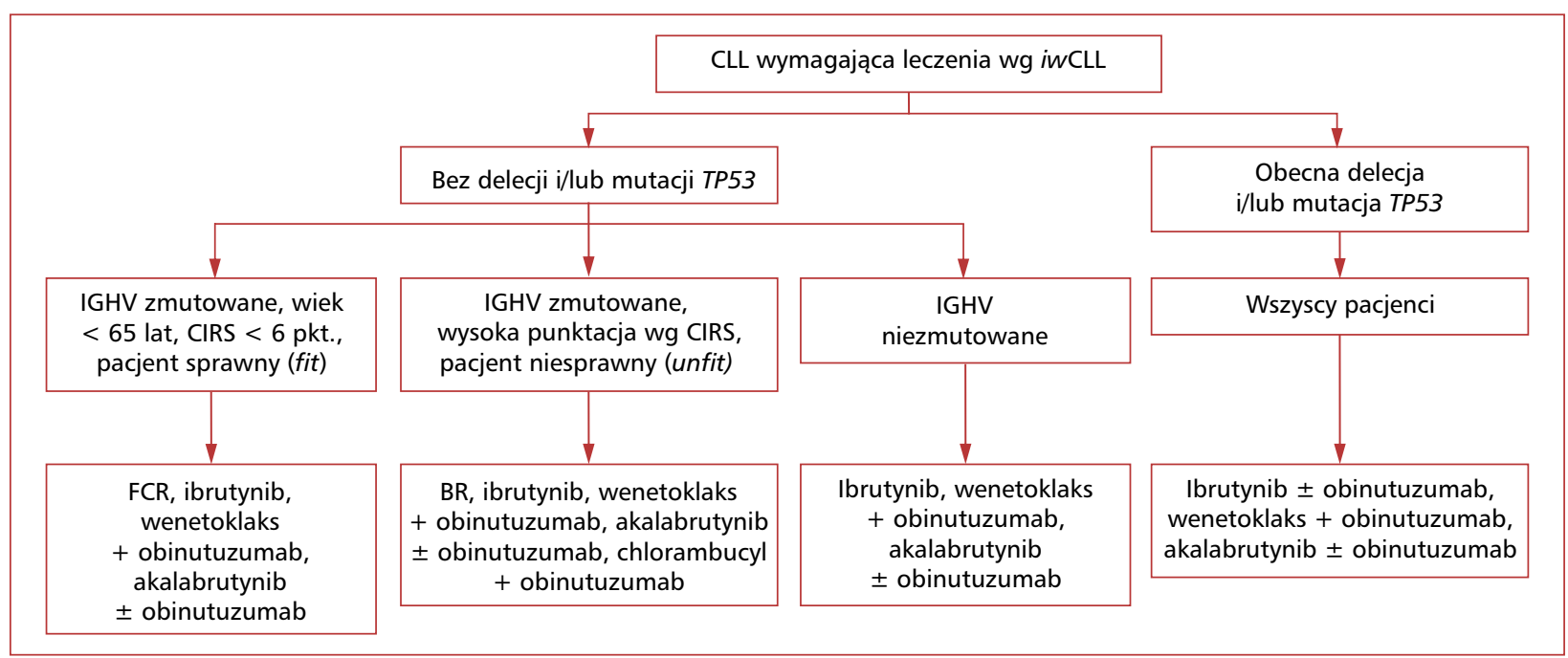

Rycina 1. Wybór terapii pierwszej linii nieleczonych pacjentów z przewlekłą białaczką limfocytową (CLL, chronic lymphocytic leukaemia) — zalecane schematy zależą od obecności delecji/mutacji TP53, stanu zmutowania łańcuchów ciężkich immunoglobulin (IGHV, immunoglobulin heavy chain), wieku, stanu sprawności pacjenta i schorzeń współistniejących. Schemat zmodyfikowany na podstawie aktualnych zaleceń ESMO (European Society for Medical Oncology) [4] oraz NCCN (National Comprehensive Cancer Network) [5], nie uwzględnia dostępności (refundacji) leków; iwCLL (International Working Group-CLL) - Międzynarodowa Grupa Robocza dla CLL; CIRS - Cumulative IIIness Rating Scale; FCR — fludarabina, cyklofosfamid, rytuksymab; BR — bendamustyna, rytuksymab

ponse), stabilizację choroby (SD, stable disease) i progresję choroby ( $\mathrm{PD}$, progressive disease), ocenia się na podstawie wytycznych $i w$ CLL, według których u pacjentów poza badaniami klinicznymi konieczne są ocena węzłów chłonnych, wielkości wątroby i śledziony (badanie przedmiotowe i ultrasonograficznej [USG] jamy brzusznej), obecności objawów układowych oraz ocena morfologii krwi. Badanie tomografii komputerowej (CT, computed tomography) i biopsja szpiku są wykonywane w ramach badań klinicznych (ta ostatnia również w przypadku cytopenii). Coraz częściej w badaniach klinicznych ocenia się MRD, ponieważ wykazano korelację między eradykacją MRD a wydłużeniem parametrów przeżycia $[1,2]$.

U osób $z$ chorobą nawrotową kliniczne wskazania do rozpoczęcia leczenia są takie, jak u pacjentów nieleczonych. Podobne są również uwarunkowania związane $z$ wiekiem, stanem ogólnym pacjenta, chorobami wspólistniejącymi, występowaniem zaburzeń genetycznych i zmian immunofenotypowych. Pod uwagę należy wziąć także czas trwania remisji. W przypadku remisji dłuższej niż 3 lata można rozważyć zastosowanie schematu wykorzystywanego w pierwszej linii. W innych przypadkach należy zastosować lek o innym mechanizmie działania, biorąc pod uwagę wymienione wyżej czynniki, a także profil działań niepożądanych. U młodszych pacjentów, bez chorób współistniejących, ale ze zmianami w genie TP53 leczonych inhibitorami kinaz czy anty-BCL2, w przypadku pierwszego nawrotu należy rozważać kwalifikację do allogenicznego przeszczepienia szpiku pod warunkiem uzyskania odpowiedzi na drugą linię terapii [1, 2, 5-7].

\section{Opis przypadku}

Pacjent w wieku 36 lat, do tej pory nieleczony, zgłosił się do kliniki onkologicznej w maju 2015 roku $z$ powodu powiększonych szyjnych węzłów chłonnych. U chorego wykonano CT, w której ujawniono liczne powiększone węzły chłonne do $36 \mathrm{~mm}$ w okolicy krezki. Narządy miąższowe były bez zmian. Pacjent był w dobrym stanie ogólnym, negował typowe objawy układowe. $\mathrm{W}$ badaniu przedmiotowym spośród odchyleń stwierdzono drobne węzły chłonne szyjne, pachowe i pachwinowe do $1,5 \mathrm{~cm}$. Pobrano szyjny węzeł chłonny do badania histopatologicznego, którego wynik pozwolił rozpoznać chłoniaka $z$ małych limfocytów B (SLL)/CLL. Immunohistochemicznie komórki nowotworu były CD20+, CD5+, CD23+, ZAP70+, BCL6-, a wskaźnik Ki67+ wyniósł do $20 \%$ w centrach limfoproliferacyjnych. W badaniu krwi nie stwierdzono leuko- ani limfocytozy (LYM, lymphocytosis) (leukocytoza, tj. liczba krwinek białych 
[WBC, white blood cells] wynosiła 5,12 G/1 [norma $\{\mathrm{N}\}: 4,0-10,0]$, LYM wynosiła $1,27 \mathrm{G} / 1$ [N:1,5-3,0], stężenie Hb i liczba płytek krwi [PLT, platelets] były prawidłowe i wynosiły, odpowiednio, $17,5 \mathrm{~g} / \mathrm{dl}$, [N: 14,0-18,0] oraz $145 \mathrm{G} / 1$ [N: 148-400]); stężenie $\beta_{2}$-mikroglobuliny było miernie podwyższone i miało wartość $2,05 \mathrm{mg} / 1$ (N: 0,7-1,8). Pogłębiono diagnostykę w celu określenia czynników rokowniczych i wykonano punkcję cienkoigłową $z$ pobraniem materiału na badanie cytogenetyczne i cytometrii przepływowej. Ostateczne rozpoznano chłoniaka $z$ małych limfocytów B (SLL) ZAP70+/ /CD38-/CD49d+/CD305-/CD71+ o profilu ekspresji antygenów wskazującym na postać niezmutowaną $z$ profilem białek (CD305-, CD49d+, ZAP70+) wskazującym na gorsze rokowanie. Klasyczne badanie cytogenetyczne wykazało prawidłowy kariotyp męski 46,XY(19), będący czynnikiem pośredniego rokowania, a badanie fluorescencyjnej hybrydyzacji in situ (FISH, fluorescence in situ hybridization) - brak zaburzeń o uznanym znaczeniu rokowniczym w obrębie genów TP53, ATM, delecji 13q14 i trisomii chromosomu 12. Stopień zaawansowania według Bineta określono jako A, a wskaźnik prognostyczny dla CLL (CLL-IPI) wyniósł 2, co pozwoliło zakwalifikować pacjenta do grupy o pośrednim rokowaniu, $z$ oczekiwanym czasem 5-letniego OS wynoszącym 79,3\%. Zgodnie $z$ zaleceniami iwCLL pacjenta poddano obserwacji. W listopadzie 2017 roku w trakcie kolejnego badania kontrolnego chory zgłosił okresowe poty nocne i nawracające infekcje. W badaniu przedmiotowym stwierdzono liczne powiększone węzły chłonne szyjne, podzuchwowe, nadobojczykowe, pachowe, pachwinowe, łączące się w pakiety, o maksymalnych wymiarach do $5 \mathrm{~cm}$ i splenomegalię. Wykonano CT, w którym opisano powiększone węzły chłonne w śródpiersiu i wnękach do $51 \mathrm{~mm}$. Śledziona była znacznie powiększona o wymiarze 19,2 cm; stwierdzono masywne zmiany węzłowe w jamie brzusznej. Zlewające się pakiety węzłów krezkowych i trzewnych wypełniały nadbrzusze i śródbrzusze, sięgały ku miednicy mniejszej, otaczały duże naczynia i przemieszczały trzustkę do przodu. W badaniach krwi uwagę zwracały leuko- i limfocytoza (WBC 19,4 G/1, LYM 14,4 G/1 [74\%], neutrocyty [NEU] 4,03 G/1 [20,8\%], obniżona do $123 \mathrm{G} / 1$ liczba PLT; Hb w normie $14,3 \mathrm{~g} / \mathrm{dl}$; zwiększone stężenie $\beta_{2}$-mikroglobuliny $-4,79 \mathrm{mg} / \mathrm{l})$. W badaniu cytometrii przepływowej krwi opisano zajęcie przez patologiczną populację komórek CD38+/-/ZAP70+/CD49d-/+/CD305-/ /CD71+ - na poziomie około 7200 komórek w $1 \mathrm{~mm}^{3}$ krwi obwodowej, co stanowiło $40 \%$ jądrzastych elementów morfotycznych krwi. Materiał przekazano do badań cytogenetycznych, w których wykazano pojawienie się delecji w 56\% komórek (nieobecnej w badaniu z 2015 r.) w regionie 11q (delecja $A T M$ potwierdzona w badaniu FISH), co świadczyło o klonalnej ewolucji cytogenetycznej będącej niekorzystnym czynnikiem rokowniczym. Wskaźnik CLL-IPI wyniósł 5, co oznaczało grupę wysokiego ryzyka $z$ 5-letnim OS wynoszącym $62,9 \%$. Zgodnie $z$ obowiązującymi wówczas wytycznymi i dostępnością leków chorego zakwalifikowano do immunochemioterapii według schematu R-FC i od stycznia do czerwca 2018 roku otrzymał sześć kursów w dawkach należnych, uzyskując całkowitą remisję w obrębie obwodowych węzłów chłonnych, znaczne zmniejszenie węzłów chłonnych w jamie brzusznej i regresję wymiarów śledziony. W morfologii stwierdzono zmniejszenie liczby leukocytów i limfocytów (WBC 3,97 G/1, LYM 0,32 G/L [8,1\%], NEU 2,93 G/1 [73,8\%]), zwiększenie do $183 \mathrm{G} / 1$ liczby PLT i stężenia Hb do $16,8 \mathrm{~g} / \mathrm{dl}$; stężenie $\beta_{2-}$ mikroglobuliny wynosiło $1,62 \mathrm{mg} / 1$. Według kryteriów klinicznych $i w$ CLL pacjent osiągnął remisję całkowitą i został poddany obserwacji. W październiku 2019 roku, $\mathrm{w}$ trakcie badania kontrolnego, ponownie ujawniono leuko- i limfocytozę (WBC 16,56 G/l, NEU $16,1 \%$, LYM 56,3\% [9,33 G/1]) — podwojenie przez 4 miesiące i zmniejszenie liczby PLT do $121 \mathrm{G} / \mathrm{l}$. Pacjent czuł się dobrze, ale $\mathrm{w}$ badaniu przedmiotowym stwierdzono dyskretne powiększenie węzłów chłonnych szyjnych i pachowych nieprzekraczające $2 \mathrm{~cm}$. Trzy miesiące później, w styczniu 2020 roku, chory zgłosił pojawienie się potów nocnych, bólów brzucha, chudnięcie i osłabienie. W badaniu przedmiotowym zaznaczała się znaczna limfadenopatia nad-i podprzeponowa; węzły chłonne łączyły się w pakiety o wymiarach ponad $5 \mathrm{~cm}$. W CT uwidoczniono ponadto liczne powiększone węzły chłonne w klatce piersiowej oraz $\mathrm{w}$ jamie brzusznej; w lokalizacjach tych opisano masywne pakiety węzłowe, $z$ których największy, otaczający naczynia w krezce, dochodził do $162 \times 86 \mathrm{~mm}$, pozostałe w nadbrzuszu powyżej pnia trzewnego miały wymiary $103 \times 66 \mathrm{~mm}$, a okołoaortalne $91 \times 82 \mathrm{~mm}$. Śledziona była znacznie powiększona — do $186 \mathrm{~mm}$ w osi długiej. Opisano również naciek jelita cienkiego i wolny płyn w jamie otrzewnej. W badaniach laboratoryjnych wykazano wzrost leuko- i limfocytozy (WBC 135 G/l; LYM 115 G/1 [85\%]), zmniejszenie stężenia $\mathrm{Hb}$ do $11,7 \mathrm{~g} / \mathrm{dl}$, obniżenie liczby PLT do 45 G/l, wzrost aktywności dehydrogenazy mleczanowej (LDH, lactate dehydrogenase) $1106 \mathrm{jm} . / 1(\mathrm{~N}:<247 \mathrm{jm} . / 1)$, wzrost stężeń mocznika 
$55 \mathrm{mg} / \mathrm{dl}(\mathrm{N}: 17,0-43,0)$ i kreatyniny $1,25 \mathrm{mg} / \mathrm{dl}$ $(0,67-1,17)$ oraz szacowany współczynnik przesączania kłębuszkowego (eGFR, estimated glomerular filtration rate) wynoszący $64 \mathrm{ml} / \mathrm{min} / \mathrm{m}^{2}(\mathrm{~N}: \geq 90 \mathrm{ml} /$ $\left./ \mathrm{min} / 1,73 \mathrm{~m}^{2}\right)$. W celu wykluczenia zespołu Richtera wykonano nakłucie węzła chłonnego $z$ badaniem cytometrycznym i cytogenetycznyn zgodnie $z$ obowiązującym algorytmem [8]. Cytometrycznie nie potwierdzono transformacji do agresywnego chłoniaka, natomiast cytogenetycznie w stosunku do poprzedniego badania $z 2017$ roku stwierdzono pojawienie się bardzo licznego klonu $z$ nieobecną wcześniej delecją 17p, pojawienie się klonu $z$ nieobecną wcześniej delecją 13q14 oraz zmniejszenie się klonu $z$ obecną wcześniej delecją ATM. Wynik ten wskazywał na ewolucję klonalną i potwierdził progresję choroby do postaci o agresywnym przebiegu klinicznym. Wystąpienie delecji 17p znacznie pogorszyło rokowanie pacjenta, którego wskaźnik rokowniczy CLL-IPI wyniósł 9, co równa się bardzo wysokiemu ryzyku i oznacza 5-letnie przeżycie rzędu $23,9 \%$. Według aktualnych rekomendacji u chorego ze zmianami w obrębie genu TP53 należy stosować terapię nowymi lekami - inhibitorami BTK lub blokerami białka antyapoptotycznego BCL2. Oba leki są dostępne w Polsce w ramach programu lekowego. Ze względu na konieczność uzyskania szybkiego efektu terapeutycznego (pacjent $z$ masywnymi zmianami węzłowymi, uciskającymi na narządy wewnętrzne, objawami układowymi, małopłytkowością), ograniczony czas trwania terapii i jej wysoką skuteczność oraz profil przemijających działań niepożądanych zdecydowano o włączeniu pacjenta do programu lekowego umożliwiającego stosowanie wenetoklaksu $\mathrm{z}$ rytuksymabem, do którego chory mógł być zakwalifikowany zarówno ze względu na obecności delecji 17 p, jak i szybki nawrót choroby ( $<18$ mies.) po pierwszej linii immunochemioterapii. Pacjent rozpoczął leczenie w lutym 2020 roku. Ze względu na wysokie ryzyko wystąpienia zespołu lizy guza (TLS, tumor lysis syndrome) wynikające $z$ samej obecności dużych zmian węzłowych ponad $5 \mathrm{~cm}$ oraz limfocytozy przekraczającej 25 G/1 leczenie rozpoczęto w warunkach szpitalnych. Zastosowano nawodnienie dożylne - wlew ciągły $200 \mathrm{ml} / \mathrm{h}$ i doustne $2000 \mathrm{ml} /$ dobę, rasburykazę w dawce $0,2 \mathrm{mg} /$ /kg mc., allopurinol w dawce $600 \mathrm{mg} /$ dobę $2 \mathrm{dni}$ przed pierwszą dawką wenetoklaksu i od 10 lutego 2020 roku rozpoczęto leczenie wenetoklaksem — od dawki $20 \mathrm{mg}$ /dobę przez $7 \mathrm{dni}$, z miareczkowaniem zaplanowanym na 5 tygodni do osiągnięcia dawki docelowej $400 \mathrm{mg}$ /dobę. W 5. dobie podawa- nia leku wystąpiły niedokrwistość, małopłytkowość i neutropenia 4. stopnia (WBC 4,67 G/l, NEU 0,26 G/l, PLT 12 G/l, Hb 6,6 g/dl). Pacjent otrzymywał czynnik stymulujący wzrost kolonii granulocytów (G-CSF, granulocyte-colony stimulating factor), wymagal przetaczania koncentratów krwinek czerwonych i krwinek płytkowych. $Z$ powodu toksyczności hematologicznej 4. stopnia leczenie przerwano na 2 dni, zgodnie $z$ charakterystyką produktu leczniczego (ChPL). Ponadto wystąpiły stany gorączkowe, których czynnika etiologicznego nie udało się ustalić. Stan pacjenta ulegał stopniowej poprawie; stwierdzono znaczną zmniejszenie liczby WBC do 4,9 G/L; po początkowym spadku - zwiększenie liczby PLT i stężenia $\mathrm{Hb}$, a ponadto zmniejszenie aktywności $\mathrm{LDH}$, normalizację parametrów nerkowych, znaczną regresję obwodowych zmian węzłowych i poprawę kliniczną stanu pacjenta. Chorego wypisano do domu w 6. dobie przyjmowania wenetoklaksu w dawce $50 \mathrm{mg}, \mathrm{z}$ następującymi wynikami morfologii: liczba WBC 4,98 G/l, liczba NEU 0,56 G/l, stężenie Hb 9,1 g/dl, liczba PLT 49 G/1. Pacjent kontynuował leczenie wenetoklaksem $\mathrm{w}$ warunkach ambulatoryjnych - dawkę zwiększano zgodnie $z$ ChPL do $400 \mathrm{mg}$. W trakcie eskalacji dawki i w kolejnych ty-godniach po jej osiągnięciu utrzymywała się neutropenia 3. stopnia, ale leczenie kontynuowano równolegle $z$ podawaniem G-CSF, aby utrzymać liczbę NEU ponad $1 \mathrm{G} / 1$. Po osiągnięciu dawki $400 \mathrm{mg}$ zaobserwowano zwiększenie liczby PLT do 133 G/1 i stężenia $\mathrm{Hb}$ do $9,8 \mathrm{~g} / \mathrm{dl}$, liczba WBC wynosiła 8,26 G/1, a NEU 7,24 G/l. 31 marca 2020 roku podano jedną dawkę rytuksymabu $375 \mathrm{mg} / \mathrm{m}^{2}$, kolejne dawki $500 \mathrm{mg} / \mathrm{m}^{2}$ chory otrzymywał co 4 tygodnie do 18 sierpnia 2020 roku. 1 lipca 2020 roku wykonano CT, w którym opisano znaczne zmniejszenie zmian węzłowych: „węzły chłonne szyjne i pachowe niepowiększone, węzły chłonne trzewne i zaotrzewnowe hipodensyjne, liczne maks. do $15 \mathrm{~mm}$ w osi krótkiej. Śledziona mniejsza niż poprzednio, $138 \mathrm{~mm}$. Mniejsza rozległość pogrubienia ścian jelita cienkiego w lewym śródbrzuszu”. Pacjent otrzymał sześć dawek rytuksymabu, a obecnie kontynuuje leczenie wentoklaksem w dawce $400 \mathrm{mg}$ /dobę, które jest zaplanowane na kolejne 18 miesięcy. W morfologii krwi obwodowej z 13 października 2020 roku stwierdzono: stężenie $\mathrm{Hb}$ 16,8 g/dl, liczbę PLT 136 G/1, liczbę WBC 3,86 G/1, liczbę NEU 2,56 G/1 $(66,2 \%)$, LYM 0,72 G/l (18,7\%). Pacjent czuje się dobrze; nie ma poczucia choroby ani objawów układowych. 


\section{Dyskusja}

Powyższy opis przypadku pozwala się zastanowić nad kilkoma problemami, na jakie można napotkać w trakcie leczenia pacjentów z CLL. Opisany chory w chwili rozpoznania miał 36 lat. Pacjenci w wieku poniżej 50-55 lat stanowią zaledwie 5-11\% wszystkich chorych $z$ CLL, ale retrospektywna analiza $z 2014$ roku 844 pacjentów $z$ CLL leczonych w Mayo Clinic wskazuje, że w grupie poniżej 55 . roku życia częściej występują niekorzystne czynniki rokownicze, takie jak postać niezmutowana IGHV ( $=0,002), Z A P-70+(p=0,009)$ i wyższy stopień zaawansowania klinicznego według Raia $(\mathrm{p}<0,0001)$. Przekłada się to na krótszy czas do rozpoczęcia leczenia niż u pacjentów w starszym wieku (4 lata vs. 5,2 roku; $\mathrm{p}=0,001$ ). Przeżycie całkowite u chorych młodszych było dłuższe niż u tych powyżej 55. roku życia $(12,5 v$ s. 9,5 roku; $\mathrm{p}<0,0001$ ), ale znacząco krótsze w porównaniu z dobraną pod względem płci i wieku kohortą zdrowej populacji (12,5 roku vs. nieosiągnięty; $\mathrm{p}<0,0001$ ) [9]. W cytowanej analizie nie stwierdzono poprawy w zakresie OS u młodszych pacjentów w porównaniu $z$ grupą historyczną, ale miało to miejsce przed erą nowych leków. Należy pamiętać, że wiele badań klinicznych jest ukierunkowanych na pacjentów starszych i/lub z chorobami współistniejącymi i brakuje dużych liczebnie badań zaprojektowanych dla chorych młodszych, ale oni niewątpliwie również odnoszą korzyść $z$ leczenia celowanego. Dlatego na przykład istnieją rekomendacje NCCN (National Comprehensive Cancer Network) zastosowania w pierwszej linii schematu wenetoklaks + obinutuzumab również u chorych poniżej 65 . roku życia i bez obciążeń, mimo że badanie rejestracyjne CLL14 obejmowało populację pacjentów starszych i z CIRS ponad 6 [5].

Agresywny przebieg kliniczny choroby u opisanego pacjenta przypomina o konieczności wykonywania oceny biologicznych czynników rokowniczych nie tylko wyjściowo, ale za każdym razem przy progresji choroby i kwalifikacji do leczenia. Jest to szczególnie istotne $\mathrm{w}$ polskich warunkach, w których ograniczony jest dostęp do refundacji nowoczesnych leków celowanych, mających coraz szersze wskazania rejestracyjne. Wykrycie obecności aberracji w obrębie TP53, które wiążą się $z$ opornością na klasyczną immunochemioterapię, nakazuje zastosowanie leku $z$ grupy inhibitorów BTK lub BCL2. W tym przypadku początkowa cytometria przepływowa wskazywała na możliwy niekorzystny przebieg choroby ze względu na ekspresję białek CD305-, CD49d+,
ZAP70+, mimo braku ekspresji CD38, ale w badaniu kariotypu i FISH nie stwierdzono obecności negatywnych czynników rokowniczych. Analiza wykonana przy pierwszej progresji choroby wskazała na progresję klonalną $z$ niekorzystną delecją 11q, a przy drugiej na pojawienie się kolejnego klonu $\mathrm{z}$ najgorzej rokującą zmianą - delecją $17 \mathrm{p}$, co umożliwiło zastosowanie leczenia celowanego o znacznie większej skuteczności niż tradycyjna immunochemioterapia. Należy pamiętać, że w rekomendacjach dotyczących oceny zaburzeń w obrębie genu TP53 istotne jest badanie nie tylko delecji, ale również mutacji, ponieważ u części pacjentów przy braku delecji występuje mutacja, która ma równie niekorzystny wpływ na przeżycie [10]. Częstość występowania zaburzeń w obrębie TP53 zwiększa się wraz z przebiegiem choroby i kolejnymi liniami leczenia. Badaniem, które również powinno być wykonywane, jest ocena stopnia zmutowania genów IGHV, ponieważ pacjentów $z$ postacią niezmutowaną cechuje gorsze rokowanie, a w aktualnych rekomendacjach zaleca się leczenie takich chorych w pierwszej linii nowymi lekami, a nie tradycyjną immunochemioterapią. Nie ma to, niestety, przełożenia na praktykę w polskich warunkach $z$ powodu braku refundacji tych preparatów w tym wskazaniu, ale pacjentom powinna być zapewniona możliwość wykonania takiego badania, $z$ myślą o rozszerzającym się dostępie do nowoczesnego leczenia. Uznaną metodą oceny stopnia zmutowania IGHV jest diagnostyka molekularna według wytycznych ERIC (European Research Initiative on CLL), w ramach której przeprowadza się namnażanie tranksryptu IGHV w badaniu metodą reakcji polimerazy łańcuchowej (PCR, polymerase chain reaction) i następnie sekwencjonowanie metodą Sangera i porównanie do znanych sekwencji genów immunoglobulin [11, 12].

Przy omawianiu diagnostyki u tego pacjenta należy te $\dot{z}$ wspomnieć o ryzyku transformacji Richtera, która zdarza się u 2-10\% chorych [13]. Szybkie zwiększenie wymiarów mas węzłowych, naciekanie narządów wewnętrznych, wysokie stężenia LDH i kwasu moczowego oraz objawy układowe mogły nasuwać podejrzenie wystąpienia zespołu Richtera, dlatego celem wykonania punkcji cienkoigłowej i cytometrii przepływowej było wykluczenie tej niekorzystnie rokującej transformacji choroby.

Zastosowanie immunochemioterapii R-FC $\mathrm{u}$ przedstawianego pacjenta spowodowało tylko krótkotrwałą remisję, w przeciwieństwie do niektórych pacjentów ze zmutowaną postacią IGHV, którzy po leczeniu według tego protokołu mogą 
uzyskać długotrwałe remisje i długie OS, włącznie $z$ osiagnięciem plateau na krzywych PFS. Dotyczy to chorych ze zmutowanym IGHV, bez delecji/ /mutacji TP53 oraz tych, który osiągnęli eradykację MRD [14-16]. W przypadku tego pacjenta doszło do progresji choroby 15 miesięcy po zakończeniu pierwszej linii terapii, co świadczyło o agresywnej biologii tego nowotworu, którą potwierdzono w badaniu FISH, wykazując obecność delecji 17p. Jak wyżej wspomniano, pacjenci $z$ aberracjami TP53 powinni otrzymać leczenie inhibitorami BCR lub BCL2, ponieważ to zaburzenie molekularne niesie ze sobą oporność na cytostatyki i wiąże się $z$ bardzo niekorzystnym rokowaniem. Leki $z$ obu grup przebadano w tej grupie osób $z$ chorobą oporną i nawrotową i wykazały się skutecznością, chociaż nie porównano ich bezpośrednio w randomizowanym badaniu III fazy. Ibrutynib jako pierwszy zdobył rekomendację w tym wskazaniu na podstawie wyników badań RESONATE-17 i RESONATE. W tym pierwszym badaniu wzięło udział 145 pacjentów z zaburzeniami w obrębie genu TP53, u których po 24 miesiącach odsetek CR wyniósł 83\%, PFS 63\%, a OS 75\% [17]. W badaniu RESONATE u znacznego odsetka chorych w obu grupach (ibrutynib $v s$. ofatumumab) występowała delecja i/lub mutacja TP53; analiza 3-letnia wykazała 30-miesięczny PFS wynoszący 55\% w tej podgrupie pacjentów [18]. W analizie 6-letniej mediana PFS pacjentów $z$ delecją i/lub mutacją TP53 leczonych inhibitorem BTK wyniosła 41 miesięcy $\mathrm{w}$ porównaniu $z$ medianą 57 miesięcy u chorych bez tych zaburzeń [19]. Model prognostyczny dla pacjentów leczonych ibrutynibem z 2020 roku wskazuje na aberracje w obrębie genu TP53 jako na jeden $z$ niekorzystnych czynników przeżycia, poza stężeniem $\beta_{2}$-mikroglobuliny przekraczającym $5 \mathrm{mg} / \mathrm{l}$, postacią nawrotową i oporną choroby oraz aktywnością LDH ponad 250 j./l. Ponadto autorzy pracy dowiedli, że u chorych $z$ aberracjami TP53 trzy razy częściej (38\% vs. 13\%) pojawiają się mutacje $B T K / P L C G 2$, które wiążą się z opornością na ibrutynib [20].

W 2018 roku została opublikowana analiza 158 pacjentów $z$ delecją $\mathrm{p} 17 \mathrm{z}$ badania II fazy M13-982 leczonych wentoklaksem; mediana czasu terapii wyniosła 23 miesiące; całkowity odsetek odpowiedzi (ORR, overall response rate) $77 \%$, w tym CR 20\%, a prognozowany 24 miesięczny PFS 54\%. Wynoszącą mniej niż $10^{-4}$ MRD we krwi obwodowej osiągnęło 30\% pacjentów [21]. W badaniu MURANO oceniano skuteczność wenetoklaksu $z$ rytuksymabem w postaci nawrotowej CLL — terapię tę porównano ze schematem bendamustyna $z$ rytuksymabem. W obu grupach zbliżony odsetek pacjentów miał zaburzenia w obrębie TP53: $\mathrm{w}$ grupie poddanej leczeniu eksperymentalnemu u $27 \%$ stwierdzono delecję, a u 25\% mutację TP53 (u części chorych występowały obie zmiany). Znamienne wydłużenie PFS (4-letnie PFS 57,3\% vs. $4,6 \%$ w grupie standardowo leczonej bendamustyną; współczynnik ryzyka [HR, hazard ratio]: 0,19, 95-proc. przedział ufności [CI, confidence interval]: $0,14-0,25 ; \mathrm{p}<0,0001$ ) było widoczne we wszystkich podgrupach chorych leczonych wenetoklaksem $z$ rytuksymabem, $w$ tym równie $\dot{z}$ $\mathrm{u}$ tych $\mathrm{z}$ aberracjami w obrębie TP53. U pacjentów $\mathrm{w}$ grupie poddanej leczeniu eksperymentalnemu znacząco dłuższe było również OS (4-letni OS 85,3\% vs. $66,8 \%$ [HR 0,41, 95\% CI 0,26-0,65; $\mathrm{p}<0,0001]$ ] [22]. Po 36 miesiącach $62 \%$ chorych uzyskało głęboką odpowiedź we krwi, a $16 \%$ w szpiku. Aktualizacja badania MURANO — analiza po 4 latach - ukazała się w 2020 roku. Zarówno u pacjentów $z$ delecją $17 \mathrm{p}$, jak i u chorych $\mathrm{z}$ mutacją TP53 istotnie częściej wykrywano MRD $(\mathrm{p}=0,031$ dla chorych $z$ delecją $v$ s. chorzy bez delecji). Po 36 miesiącach leczenia MRD poniżej $10^{-4}$ uzyskało od $52 \%$ (bez zmian cytogenetycznych) do $77 \%$ pacjentów (delecja 13q14), ale w przypadku aberracji TP53 odsetek ten był niższy i wyniósł $41 \%$. Pacjentów $z$ dodatnią MRD wykrywalną zarówno na niskim (między $10^{-2}$ a $10^{-4}$ ), jak i wysokim $\left(>10^{-2}\right)$ poziomie cechowały znamiennie krótsze PFS, nie przełożyło się to jednak na gorsze wyniki przeżycia $\mathrm{w}$ grupie chorych $\mathrm{z}$ delecją $17 \mathrm{p}$. Wprawdzie był u nich widoczny trend do krótszego PFS, ale nie był on istotny statystycznie w analizie wieloczynnikowej [23]. Jak już wspomniano, brakuje badania randomizowanego, w którym porównano by ibrutynib lub inny inhibitor BTK $z$ wenetoklaksem w leczeniu nawrotu po immunochemioterapii. W przytoczonych wyżej publikacjach widoczna jest istotnie większa skuteczność zarówno inhibitorów BTK, jak i BCL2 w nawrotowych i opornych postaciach CLL w porównaniu $z$ immunochemioterapią. Dotyczy ona także pacjentów ze zmianami w obrębie TP53. Chociaż w analizach podsumowujących dłuższy czas obserwacji widoczny jest trend do krótszego czasu przeżycia tej subpopulacji pacjentów $\mathrm{w}$ porównaniu $\mathrm{z}$ grupą bez aberracji TP53, to terapia lekami celowanymi jest „złotym standardem” leczenia tych chorych, ponieważ istotnie poprawia parametry przeżycia. Oba leki — ibrutynib i wenetoklaks — są rekomendowane w leczeniu postaci nawrotowych i opornych $\mathrm{z}$ aberracjami TP53 (równorzędnie kategoria 1 w zaleceniach NCCN; również w tym wskazaniu 
kategorię 1 ma akalabrutynib - inhibitor BTK 2 generacji, nieomawiany w tym artykule) [5]. W 2020 roku ukazała się retrospektywna analiza, w której porównano zastosowanie ibrutynibu oraz wenetoklaksu jako pierwszego małocząsteczkowego inhibitora w przypadkach nawrotowej CLL [24]. Analizą objęto 433 pacjentów $z$ nawrotowym CLL, którzy wcześniej nie otrzymywali leczenia inhibitorami BTK ani BCL2. Mediana wcześniejszych linii leczenia wyniosła dwa. Grupy różniły się liczebnie; 385 chorych otrzymało ibrutynib, a 48 wenetoklaks, ale poza tym kohorty były zbliżone pod względem mediany poprzednich linii leczenia (2), wieku, obecności delecji 17p czy złożonego kariotypu. Odsetki ORR i CR w grupie leczonej ibrutynibem wyniosły $71 \%$ i $12 \%$, wenetoklaksem - $96 \%$ i $56 \%$, a różnica w CR na korzyść wenetoklaksu była istotna statystycznie $(p<0,001)$. Nie stwierdzono różnic pod względem OS, natomiast PFS było dłuższe u pacjentów leczonych wenetoklaksem $(\mathrm{HR}=0,29$, 95\% CI: $0,10-0,92 ; p=0,036)$. W obu grupach były zbliżone odsetki chorych wymagających zmniejszenia dawki oraz przerwy w dawkowaniu (22\% i 33\% dla ibrutynibu, 26\% i 32\% dla wenetoklaksu). Natomiast mniejsza część chorych leczonych wenetoklaksem przerwała na trwale terapię $(25 \%)$ w porównaniu $z$ ibrutynibem (41\%), przy czym najczęstszą przyczyną dyskontynuacji w pierwszym przypadku była procedura allogenicznego przeszczepienia szpiku, a w drugim - działania niepożądane. Autorzy analizy wnioskują, że przy braku badania randomizowanego, w którym porównano by oba leki, i braku różnic w OS w obu grupach pacjentów, można uznać, że mają one pozycję równorzędną u pacjentów w pierwszym nawrocie po immunochemioterapii. Wybór inhibitora BTK czy BCL2 powinien być warunkowany profilem działań niepożądanych oraz preferencjami pacjenta i lekarza, dotyczącymi między innymi czasu terapii (przewlekły vs. ograniczony) i szybkości uzyskania efektu terapeutycznego. W opisanym wyżej przypadku o wyborze terapii zdecydowały wysoce agresywny przebieg kliniczny i spodziewane szybkie osiągnięcie efektu leczniczego oraz poprawy stanu chorego, zakres działań niepożądanych i ograniczony czas leczenia. Wzięto pod uwagę aktywny tryb życia chorego, dla którego ważna była perspektywa czasowa zakończenia terapii. Należy tu wspomnieć o najczęstszych działaniach niepożądanych występujących w trakcie leczenia wenetoklaksem, do których należą neutropenia (40\%), małopłytkowość (21\%), biegunka (41\%), nudności (39\%) i infekcje górnych dróg oddechowych (25\%). W badaniu MURANO u 3\% pacjentów opisano TLS. $Z$ opublikowanych później doniesień obejmujących rezultaty trzech badań klinicznych wynika, że w tej populacji chorych przy właściwym postępowaniu laboratoryjny TLS wystąpił tylko u $1,4 \%$, a kliniczny nie został w ogóle odnotowany [25]. $Z$ kolei analiza retrospektywna 297 pacjentów wykazała, że laboratoryjny TLS miał miejsce u $5,7 \%$ chorych, a kliniczny u $2,7 \%$ [26]. Ryzyko wystąpienia tego zespołu zależy od takich czynników, jak wysoka - przekraczająca $25 \mathrm{G} / 1-$ limfocytoza, duże - ponad $5 \mathrm{~cm}-$ wymiary zmian węzłowych, obniżony - poniżej $80 \mathrm{ml} / \mathrm{min} / \mathrm{m}^{2}$ - klirens kreatyniny, zaburzenia biochemiczne, wspólistnienie innych chorób. W celu jego uniknięcia należy stosować miareczkowanie leku, odpowiednie nawodnienie doustne i allopurinol, a przy dużym ryzyku - dodatkowo rasburykazę, wlew ciągły płynów oraz często kontrolować parametry biochemiczne krwi obwodowej. Dawka terapeutyczna, wynosząca od 20 do $400 \mathrm{mg} /$ /dobę, powinna zostać osiągnięta w ciągu 5 tygodni. Wenetoklaks jest lekiem o działaniu mielosupresyjnym. W badaniu MURANO neutropenia wystąpiła u $61 \%$ pacjentów, gorączka neutropeniczna u 4\%; w badaniu CLL14 neutropenię co najmniej 3. stopnia stwierdzono u $53 \%$ i zakażenia co najmniej 3. stopnia u $18 \%$ chorych w obu badaniach [27]. W przypadku wystąpienia neutropenii 3. i/lub 4. stopnia $z$ gorączką/zakażeniem, a także innych toksyczności hematologicznych 4 . stopnia ( $z$ wyjątkiem limfopenii) wenetoklaks należy przerwać. Trzeba pamiętać o tym, że cytopenie w znacznej mierze wynikają $z$ nacieczenia szpiku przez CLL, dlatego rekomenduje się, aby w celu umożliwienia szybkiego osiagniecia dawki terapeutycznej stosować G-CSF w fazie miareczkowania i w pierwszych 3-4 miesiącach leczenia, tak aby utrzymać NEU powyżej $1 \mathrm{G} / 1$ [28]. Osiągnięcie w krótkim czasie dawki docelowej wenetoklaksu pozwala na powrót prawidłowej czynności szpiku i normalizację parametrów krwi obwodowej, co można było zaobserwować w opisanym wyżej przypadku.

Jak wspomniano, brakuje badań prospektywnych, w których porównano by bezpośrednio wenetoklaks $z$ ibrutynibem w leczeniu nawrotowej postaci CLL, zwłaszcza u chorych $z$ aberracjami TP53. Oba leki mają równorzędne rekomendacje $\mathrm{w}$ tej grupie pacjentów w nawrocie choroby po immunochemioterapii [4]. Brakuje również badań odpowiadających na pytanie o optymalną kolejność zastosowania tych leków w tej populacji chorych. Więcej jest publikacji opisujących skuteczność wenetoklaksu w przypadku progresji choroby $\mathrm{w}$ trakcie leczenia ibrutynibem lub nawrotu [29, 30]. 
W 2018 roku opisano grupę 91 pacjentów, $z$ których $55 \%$ przerwało leczenie ibrutynibem $z$ powodu progresji choroby, a 33\% z powodu działań niepożądanych. Wdrożenie leczenia inhibitorem BCL2 było postępowaniem skutecznym, a ORR wyniosło $65 \%$ (59 chorych), w tym u 8 (9\%) była to CR [29]. Dobrą odpowiedź na wenetoklaks zaobserwowano również w podgrupie chorych $\mathrm{z}$ aberracjami TP53: $61 \%$ (95\% CI: $45 \%, 75 \%$ ) w porównaniu z $67 \%$ (95\% CI: $51 \%, 80 \%)$ dla chorych bez tych zmian. Przełożyło się to na zbliżone PFS - szacowane 12-miesięczne PFS wyniosło $72 \%$ (95\% CI: $56 \%$, 83\%) u pacjentów ze zmianami w TP53 w porównaniu z 79\% (95\% CI: 64\%, 89\%) u pozostałych pacjentów. Prognozowane 12-miesięczne OS było takie samo w obu podgrupach chorych i wyniosło 91\% (95\% CI: 78\%, 97\%). Należy podkreślić, że PFS w grupie chorych z mutacjami BTK i PCLG2, które wiążą się $z$ opornością na ibrutynib, nie różniło się od przeżycia w pozostałej grupie chorych. W 2019 roku opublikowano pracę, w której przeanalizowano dane 436 chorych $z 4$ badań wczesnej fazy $z$ zastosowaniem wenetoklaksu w postaci nawrotowej CLL [30]. Odsetek ORR wyniósł 75\%, w tym $22 \%$ CR. Szacowane mediany PFS, czasu trwania odpowiedzi (DoR, duration of response) i czasu do progresji wyniosły, odpowiednio, 30,2, 38,4, i 36,9 miesiąca. Pacjentów z delecją 17p i/lub mutacjami TP53 oraz mutacjami NOTCH1 cechowało takie samo prawdopodobieństwo uzyskania odpowiedzi na leczenie wenetoklaksem, ale krótszy DoR. Również chorych opornych na inhibitory kinaz i z masywną limfadenopatią, wynoszącą co najmniej $5 \mathrm{~cm}$, cechowały niższy odsetek CR i krótszy DoR.

Znacznie mniej jest doniesień dotyczących leczenia inhibitorami BTK po wcześniejszym zastosowaniu wenetoklaksu. Dane $z$ tych publikacji są jednak zachęcające i ukazują skuteczność takiej strategii. W 4-letniej analizie badania MURANO opisano 12 pacjentów, u których doszło do progresji choroby po leczeniu wentoklaksem i rytuksymabem; otrzymali oni ibrutynib, a ORR wyniósł 100\%; u 3 chorych doszło do progresji choroby, a 8 jest w trakcie terapii [23]. $Z$ kolei w cytowanym powyżej badaniu M13-982 wenetoklaks otrzymało 16 pacjentów leczonych uprzednio inhibitorem kinaz - ORR wyniósł 63\%, a 24-miesięczny PFS - 50\% (95\% CI: 25-71\%) [21]. Pozostałe doniesienia również obejmowały niewielkie liczebnie grupy chorych $(\mathrm{n}=8-29)$, z ORR od $56 \%$ do $100 \%$ [31, 32]. Największą grupę chorych opisano $\mathrm{w}$ wielośrodkowej pracy opublikowanej w 2020 roku [33]. Liczyła ona 326 pacjentów leczonych wenetoklaksem, u których leczenie przerwano z powodu progresji choroby (37\%), działań niepożądanych (20\%), transformacji Richtera (13\%) czy woli pacjenta lub lekarza (8\%). Pozostałe przyczyny to między innymi: planowana terapia komórkowa (7\%), śmierć $z$ innych powodów (5\%), inny nowotwór (3\%). W większości byli to pacjenci leczeni $z$ powodu choroby nawrotowej i opornej (96\%), tylko $4 \%$ poddano temu leczeniu w pierwszej linii. Mediana linii leczenia przed wenetoklaksem wyniosła trzy. U $47 \%$ chorych występowała del(17p), u 45\% mutacja TP53, u 39\% złożony kariotyp, a u $18 \%$ mutację NOTCH1. Po przerwaniu stosowania wenetoklaksu najczęściej wybieranymi lekami były inhibitory BTK $(\mathrm{n}=74$ pacjentów), inhibitory PI3K $(n=17)$, terapia limfocytami $\mathrm{T} z$ limfocyty $\mathrm{T}$ $z$ ekspresją chimerycznego receptora antygenowego (CAR-T, chimeric antigen receptor T cells) $(\mathrm{n}=18)$ i przeciwciała anty-CD20 + (n=19). Wcześniej $40 \%$ $(\mathrm{n}=130)$ chorych nie otrzymało inhibitorów BTK, a $81 \%(n=263)$ idelalisibu. Spośród pacjentów wcześniej nieeksponowanych na inhibitory BTK $84 \%(n=44)$ odpowiedziało na terapię tymi lekami i uzyskało medianę PFS 32 miesiące, natomiast wśród chorych wcześniej leczonych inhibitorami BTK odsetek ORR wyniósł 54\% $(n=30)(p<0,001)$, a mediana PFS 12 miesięcy. Pacjenci, u których wcześniej przerwano terapię $z$ powodu toksyczności ( $1 / 3$ chorych) osiąnęli istotnie dłuższe PFS (32 mies.) niż chorzy oporni na inhibitory BTK (2/3 chorych) (4 mies.). Należy podkreślić, że u pacjentów, którzy przerwali leczenie wenetoklaksem $z$ powodu progresji, a wcześniej nie otrzymywali inhibitorów BTK, mediana PFS nie została osiagnnięta. Na leczenie idelalisibem i duvelisibem odpowiedziało $47 \%$ z medianą PFS 9 miesięcy, a na anty-CD20 $+-32 \%$, ale $z$ medianą PFS zaledwie 2 miesiące. Najdłuższe PFS uzyskali pacjenci $(\mathrm{n}=19)$, którzy po leczeniu wenetoklaksem zostali poddani allogenicznemu przeszczepieniu szpiku (mediana PFS nie została osiągnięta oraz leczeni inhibitorami BTK, ale bez wcześniejszej ekspozycji na te leki (32 mies.). Autorzy pracy konkludują, że przy braku danych pochodzących $z$ badań randomizowanych przytoczona analiza wskazuje na efektywność zastosowania wenetoklaksu na wcześniejszym etapie choroby przed wdrożeniem terapii inhibitorami BTK, które $z$ kolei są skuteczną opcją leczenia w nawrocie po terapii anty-BCL2.

W cytowanej wyżej pracy poruszono kwestię roli allogenicznego przeszczepienia szpiku u pacjentów $z$ nawrotową i oporną postacią CLL. Dla tych chorych procedura ta pozostaje jedyną metodą dającą szanse na długotrwałe PFS i na wydłużenie OS [4-6, 34]. W badaniach prospektywnych 
z zastosowaniem kondycjonowania o zredukowanej intensywności (RIC, reduced-intensity conditioning) raportuje się 5- i 6-letnie przeżycia rzędu 50-63\%, a w badaniach służących porównaniu grup chorych poddanych allotransplantacji $z$ poddanymi konwencjonalnej chemioterapii - dłuższe przeżycia $\mathrm{w}$ tej pierwszej grupie [7]. Są to dane sprzed ery nowych leków i chociaż leczenie celowane $z$ zastosowaniem cząsteczek blokujących szlaki przekaźnikowe znacznie poprawiło rokowanie pacjentów obarczonych genetycznymi czynnikami ryzyka, to - jak widać na podanych powyżej przykładach - czas trwania odpowiedzi i czas do progresji są w ich przypadku krótsze, a szansa na uzyskanie wieloletniego przeżycia znacznie mniejsza. Obecnie wskazania do allotransplantacji obejmują pacjentów głównie wysokiego ryzyka (aberracje TP53, złożony kariotyp), u których dochodzi do nawrotu choroby po leczeniu $z$ zastosowaniem małocząsteczkowych inhibitorów i uzyskują odpowiedź na leczenie nowym lekiem celowanym $[4,5,7,35]$. Pod uwagę należy brać również wiek pacjenta, choroby współistniejące, czas trwania odpowiedzi i obecność dobrze dobranego dawcy $[7,35]$. Oddzielnym wskazaniem jest transformacja Richtera i CLL ze wspólistniejącym zespołem mielodysplastycznym [34]. Nawrót choroby po immunochemioterapii nie jest obecnie uznawany za wskazanie do allotransplantacji, jeśli u pacjenta nie stosowano nowoczesnych leków - blokerów $\mathrm{BCl} 2 \mathrm{i}$ inhibitorów BCR [5, 35]. Z pracy Krämer i wsp. [36] wynika, że obecność aberracji TP53 nie wpływa negatywnie na wyniki allotransplantacji, a 10-letni OS pacjentów w analizie niemieckiej grupy badawczej wyniósł $51 \%$. Wpływ natomiast mają obecność remisji przed leczeniem, w tym MRD przed i po procedurze, stan kliniczny pacjenta mierzony za pomocą HCT-CI (Hematopoietic Cell Transplantation-Comorbidity Index), w tym wiek, stan ogólny, źródło komórek (dawca spokrewniony $v$ s. niespokrewniony) oraz zastosowanie RIC $[37,38]$. W opublikowanej niedawno pracy z 2020 roku wykazano, że wyniki allotransplantacji nie różniły się niezależnie od liczby zastosowanych linii leczenia $z$ użyciem leków celowanych (1 vs. > 1) czy też ich rodzaju - inhibitorów BCR czy blokerów BCL2, a 2-letnie PFS, OS, śmiertelność niezwiązana ze wznową i odsetek wznów wyniosły, odpowiednio, $63 \%, 81 \%, 13 \%$ i $27 \%$ [39]. U pacjentów, dla których brakuje dawcy rodzinnego i niespokrewnionego, istnieje opcja haplotransplantacji z 2-letnim OS wynoszącym $48 \%$ i 5-letnim OS równym $38 \%$ [40].
Biorąc pod uwagę przebieg choroby u pacjentów wysokiego ryzyka cytogenetycznego, u opisanego chorego allogeniczne przeszczepienie szpiku jest rozważane na kolejnym etapie leczenia po terapii wenetoklaksem lub też — w zależności od preferencji pacjenta oraz możliwości doboru dawcy - po zastosowaniu w kolejnej linii inhibitora BCR.

\section{Podsumowanie}

Powyższy przypadek przedstawia rzadko występujący przykład młodego, poniżej 40. roku życia, pacjenta $z$ niekorzystnie rokującą ze względu na zaburzenia genetyczne postacią CLL. Zwrócono uwagę na konieczność badania cytogenetycznego przed rozpoczęciem leczenia i przy nawrotach choroby. Ukazano ponadto proces decyzyjny wyboru leków oparty na zaleceniach towarzystw naukowych oraz dostępności leków związanych $z$ refundacją. Podkreślone są rola i skuteczność nowych leków, opcje ich stosowania oraz przedyskutowane miejsce allogenicznego przeszczepienia szpiku jako jedynej możliwości terapii $z$ intencją radykalną $\mathrm{u}$ pacjenta $\mathrm{z}$ aberracją TP53.

\section{Konflikt interesów}

Jan Walewski: doradztwo naukowe - Roche, Abbvie, Takeda/Millenium, Gilead, Novartis; granty badawcze dla instytucji - Roche, GSK/Novartis; honoraria za wykłady - Roche, Takeda, Servier, Amgen, Abbvie, Gilead, Novartis.

Anna Dąbrowska-Iwanicka: honoraria za wykłady: Abbvie, Amgen, Astellas, Janssen-Cilag; stypendia wyazdowe: Celgene, Roche.

Katarzyna Błachnio, Grzegorz Rymkiewicz i Renata Woroniecka nie zgłaszają konfliktu interesów.

\section{Piśmiennictwo}

1. Hallek M. Chronic lymphocytic leukemia: 2020 update on diagnosis, risk stratification and treatment. Am J Hematol. 2019; 94(11): 1266-1287, doi: 10.1002/ajh.25595, indexed in Pubmed: 31364186.

2. Hallek M, Cheson BD, Catovsky D, et al. iwCLL guidelines for diagnosis, indications for treatment, response assessment, and supportive management of CLL. Blood. 2018; 131(25): 2745-2760, doi: 10.1182/blood-2017-09-806398, indexed in Pubmed: 29540348.

3. An international prognostic index for patients with chronic lymphocytic leukaemia (CLL-IPI): a meta-analysis of individual patient data. Lancet Oncol. 2016; 17(6): 779-790, doi: 10.1016/ /s1470-2045(16)30029-8. 
4. Eichhorst B, Robak T, Montserrat E, et al. ESMO Guidelines Committee. Electronic address: clinicalguidelines@esmo.org. Chronic lymphocytic leukaemia: ESMO Clinical Practice Guidelines for diagnosis, treatment and follow-up. Ann Oncol. 2021; 32(1): 23-33, doi: 10.1016/j.annonc.2020.09.019, indexed in Pubmed: 33091559.

5. NCCN Clinical Practice Guidelines in Oncology. Chronic lymphocytic leukemia/Small lymphocytic lymphoma. Version.2.2021. https://www.nccn.org/professionals/physician_gls/pdf/cll.pdf (December 3, 2020.).

6. Gelder Mv, Wreede LCde, Bornhäuser M, et al. Long-term survival of patients with CLL after allogeneic transplantation: a report from the European Society for Blood and Marrow Transplantation. Bone Marrow Transplant. 2016; 52(3): 372-380, doi: 10.1038/bmt.2016.282.

7. Gribben JG. How and when I do allogeneic transplant in CLL. Blood. 2018; 132(1): 31-39, doi: 10.1182/blood-2018-01-785998, indexed in Pubmed: 29752258.

8. Woroniecka R, Rymkiewicz G, Grygalewicz B, et al. Cytogenetic and flow cytometry evaluation of Richter syndrome reveals MYC, CDKN2A, IGH alterations with loss of CD52, CD62L and increase of CD71 antigen expression as the most frequent recurrent abnormalities. Am J Clin Pathol. 2015; 143(1): 25-35, doi: 10.1309/AJCPATRQWANW2O3N, indexed in Pubmed: 25511139.

9. Parikh SA, Rabe KG, Kay NE, et al. Chronic lymphocytic leukemia in young ( $\leq 55$ years) patients: a comprehensive analysis of prognostic factors and outcomes. Haematologica. 2014; 99(1): 140-147, doi: 10.3324/haematol.2013.086066, indexed in Pubmed: 23911703.

10. Zenz T, Eichhorst B, Busch R, et al. TP53 mutation and survival in chronic lymphocytic leukemia. J Clin Oncol. 2010; 28(29): 4473-4479, doi: 10.1200/JCO.2009.27.8762, indexed in Pubmed: 20697090.

11. Crombie J, Davids MS. IGHV mutational status testing in chronic lymphocytic leukemia. Am J Hematol. 2017; 92(12): 1393-1397, doi: 10.1002/ajh.24808, indexed in Pubmed: 28589701.

12. Zalcberg I, D'Andrea MG, Monteiro L, et al. Multidisciplinary diagnostics of chronic lymphocytic leukemia: European Research Initiative on CLL - ERIC recommendations. Hematol Transfus Cell Ther. 2020; 42(3): 269-274, doi: 10.1016/j.htct.2019.07.006, indexed in Pubmed: 31784406.

13. Tsimberidou AM, Keating MJ. Richter syndrome: biology, incidence, and therapeutic strategies. Cancer. 2005; 103(2): 216-228, doi: 10.1002/cncr.20773, indexed in Pubmed: 15578683.

14. Thompson PA, Tam CS, O'Brien SM, et al. Fludarabine, cyclophosphamide, and rituximab treatment achieves long-term disease-free survival in IGHV-mutated chronic lymphocytic leukemia. Blood. 2016; 127(3): 303-309, doi: 10.1182/ /blood-2015-09-667675, indexed in Pubmed: 26492934.

15. Fischer K, Bahlo J, Fink AM, et al. Long-term remissions after FCR chemoimmunotherapy in previously untreated patients with CLL: updated results of the CLL8 trial. Blood. 2016; 127(2): 208-215, doi: 10.1182/blood-2015-06-651125, indexed in Pubmed: 26486789.

16. Dimier N, Delmar P, Ward C, et al. A model for predicting effect of treatment on progression-free survival using MRD as a surrogate end point in CLL. Blood. 2018; 131(9): 955-962, doi: 10.1182/ /blood-2017-06-792333, indexed in Pubmed: 29255066.

17. O'Brien S, Jones JA, Coutre SE, et al. Ibrutinib for patients with relapsed or refractory chronic lymphocytic leukaemia with $17 \mathrm{p}$ deletion (RESONATE-17): a phase 2, open-label, multicentre study. Lancet Oncol. 2016; 17(10): 1409-1418, doi: 10.1016/ /S1470-2045(16)30212-1, indexed in Pubmed: 27637985.
18. Brown JR, Hillmen P, O’Brien S, et al. Extended follow-up and impact of high-risk prognostic factors from the phase 3 RESONATE study in patients with previously treated CLL/SLL. Leukemia. 2018; 32(1): 83-91, doi: 10.1038/leu.2017.175, indexed in Pubmed: 28592889.

19. Munir T, Brown JR, O'Brien S, et al. Final analysis from RESONATE: Up to six years of follow-up on ibrutinib in patients with previously treated chronic lymphocytic leukemia or small lymphocytic lymphoma. Am J Hematol. 2019; 94(12): 1353-1363, doi: 10.1002/ajh.25638, indexed in Pubmed: 31512258.

20. Ahn IE, Tian X, Ipe D, et al. Prediction of outcome in patients with chronic lymphocytic leukemia treated with ibrutinib: development and validation of a four-factor prognostic model. J Clin Oncol. 2021; 39(6): 576-585, doi: 10.1200/JCO.20.00979, indexed in Pubmed: 33026937.

21. Stilgenbauer S, Eichhorst B, Schetelig J, et al. Venetoclax for patients with chronic lymphocytic leukemia with 17 p deletion: results from the full population of a phase II pivotal trial. J Clin Oncol. 2018; 36(19): 1973-1980, doi: 10.1200/JCO.2017.76.6840, indexed in Pubmed: 29715056.

22. Kater AP, Seymour JF, Hillmen P, et al. Fixed duration of venetoclax-rituximab in relapsed/refractory chronic lymphocytic leukemia eradicates minimal residual disease and prolongs survival: post-treatment follow-up of the MURANO phase III study. J Clin Oncol. 2019; 37(4): 269-277, doi: 10.1200/JCO.18.01580, indexed in Pubmed: 30523712.

23. Kater AP, Wu JQ, Kipps T, et al. Venetoclax plus rituximab in relapsed chronic lymphocytic leukemia: 4-year results and evaluation of impact of genomic complexity and gene mutations from the MURANO phase III study. J Clin Oncol. 2020; 38(34): 4042-4054, doi: 10.1200/JCO.20.00948, indexed in Pubmed: 32986498.

24. Eyre TA, Lamanna N, Roeker LE, et al. Comparative analysis of targeted novel therapies in relapsed, refractory chronic lymphocytic leukaemia. Haematologica. 2021; 106(1): 284-287, doi: 10.3324/haematol.2019.241539, indexed in Pubmed: 32079693.

25. Davids MS, Hallek M, Wierda W, et al. Comprehensive safety analysis of venetoclax monotherapy for patients with relapsed/ /refractory chronic lymphocytic leukemia. Clin Cancer Res. 2018; 24(18): 4371-4379, doi: 10.1158/1078-0432.CCR-17-3761, indexed in Pubmed: 29895707.

26. Roeker LE, Fox CP, Eyre TA, et al. Tumor lysis, adverse events, and dose adjustments in 297 venetoclax-treated CLL patients in routine clinical practice. Clin Cancer Res. 2019; 25(14): 4264-4270, doi: 10.1158/1078-0432.CCR-19-0361, indexed in Pubmed: 31004001.

27. Kater AP, Seymour JF, Hillmen P, et al. Venetoclax-rituximab in relapsed or refractory chronic lymphocytic leukemia. N Engl J Med. 2018; 378(12): 1107-1120, doi: 10.1056/NEJMoa1713976, indexed in Pubmed: 29562156.

28. Wierda WG, Tambaro FP. How I manage CLL with venetoclax-based treatments. Blood. 2020; 135(17): 1421-1427, doi: 10.1182/ blood.2019002841, indexed in Pubmed: 32076705.

29. Jones JA, Mato AR, Wierda WG, et al. Venetoclax for chronic lymphocytic leukaemia progressing after ibrutinib: an interim analysis of a multicentre, open-label, phase 2 trial. Lancet Oncol. 2018; 19(1): 65-75, doi: 10.1016/S1470-2045(17)30909-9, indexed in Pubmed: 29246803.

30. Roberts AW, Ma S, Kipps TJ, et al. Efficacy of venetoclax in relapsed chronic lymphocytic leukemia is influenced by disease and response variables. Blood. 2019; 134(2): 111-122, doi: 10.1182/ /blood.2018882555, indexed in Pubmed: 31023700. 
31. Brown JR, Davids M, Chang J, et al. Outcomes of ibrutinib (Ibr) therapy in Ibr-naïve patients (pts) with chronic lymphocytic leukemia (CLL) progressing after venetoclax (Ven). Blood. 2019; 134(Suppl_1): 4320, doi: 10.1182/blood-2019-123665.

32. Greil R, Fraser G, Leber B, et al. Efficacy and Safety of Ibrutinib (IBR) after Venetoclax (VEN) Treatment in IBR-Naïve Patients with Relapsed/Refractory (R/R) Chronic Lymphocytic Leukemia (CLL): Follow-up of Patients from the MURANO Study. Blood. 2018; 132(Supplement 1): 5548-5548, doi: 10.1182/ /blood-2018-99-118148.

33. Mato AR, Roeker LE, Jacobs R, et al. Assessment of the efficacy of therapies following venetoclax discontinuation in CLL reveals BTK inhibition as an effective strategy. Clin Cancer Res. 2020; 26(14): 3589-3596, doi: 10.1158/1078-0432.CCR-19-3815, indexed in Pubmed: 32198151.

34. Kharfan-Dabaja MA, Kumar A, Hamadani M, et al. Clinical practice recommendations for use of allogeneic hematopoietic cell transplantation in chronic lymphocytic leukemia on behalf of the Guidelines Committee of the American Society for Blood and Marrow Transplantation. Biol Blood Marrow Transplant. 2016; 22(12): 2117-2125, doi: 10.1016/j.bbmt.2016.09.013.

35. Dreger P, Ghia P, Schetelig J, et al. European Research Initiative on CLL (ERIC) and the European Society for Blood and Marrow Transplantation (EBMT). High-risk chronic lymphocytic leukemia in the era of pathway inhibitors: integrating molecular and cellular therapies. Blood. 2018; 132(9): 892-902, doi: 10.1182/ /blood-2018-01-826008, indexed in Pubmed: 29997221.
36. Krämer I, Stilgenbauer S, Dietrich S, et al. Allogeneic hematopoietic cell transplantation for high-risk CLL: 10-year follow-up of the GCLLSG CLL3X trial. Blood. 2017; 130(12): 1477-1480, doi: 10.1182/blood-2017-04-775841, indexed in Pubmed: 28716861.

37. Kharfan-Dabaja MA, Moukalled N, Reljic T, et al. Reduced intensity is preferred over myeloablative conditioning allogeneic HCT in chronic lymphocytic leukemia whenever indicated: a systematic review/meta-analysis. Hematol Oncol Stem Cell Ther. 2018; 11(2): 53-64, doi: 10.1016/j.hemonc.2017.11.001, indexed in Pubmed: 29197550.

38. Hahn M, Böttcher S, Dietrich S, et al. Allogeneic hematopoietic stem cell transplantation for poor-risk CLL: dissecting immune-modulating strategies for disease eradication and treatment of relapse. Bone Marrow Transplant. 2015; 50(10): 1279-1285, doi: 10.1038/bmt.2015.150, indexed in Pubmed: 26146810.

39. Roeker LE, Dreger P, Brown JR, et al. Allogeneic stem cell transplantation for chronic lymphocytic leukemia in the era of novel agents. Blood Adv. Blood Adv. 2020; 25(16): 3977-3989, doi: 10.1182/bloodadvances.2020001956, indexed in Pubmed: 32841336.

40. van Gorkom G, van Gelder M, Eikema DJ, et al. CLL subcommittee, Chronic Malignancies Working Party of the EBMT. Outcomes of haploidentical stem cell transplantation for chronic lymphocytic leukemia: a retrospective study on behalf of the chronic malignancies working party of the EBMT. Bone Marrow Transplant. 2018; 53(3): 255-263, doi: 10.1038/s41409-017-0023-2, indexed in Pubmed: 29255169. 